\title{
Lean product development - principles and practices
}

\author{
Ana Julia Dal Forno, Fernando Antonio Forcellini \\ Federal University of Santa Catarina \\ e-mails: anajudalforno@hotmail.com; forcellini@gmail.com
}

\begin{abstract}
The purpose of this paper is to analyze articles about Lean Product Development. The works were classified according to principles and practices, the countries that have the applications, the sectors where it is being applied, the journals that publish articles about the issue and other relevant factors. In conclusion, the article presents a table of the authors and practices used. The methodology was a search on Emerald Insight and ISI Web of Knowledge, resulted in a universe of 289 articles published between 2007 and 2011. This paper synthesizes the trends in the literature and the results that are being obtained from the lean product development approach. The results showed that electronics, auto industry and capital goods sectors are those with the most lean product development practices presented in the articles. In terms of methodology, case studies predominate. The countries with the most applications are the United States and the United Kingdom. The lean approach is not always cited directly, in many situations the practices are applied in an isolated manner, given that in $77 \%$ of the work a direct connection was found with a lean method. In relation to the practices, the five most common were Simultaneous Engineering-Integration, Process Standardization, Early Supplier Involvement (ESI), Learning Network and Voice of Customer (VOC). Could be observed by the paper's originality that even with many studies in the field, there is still a gap to be explored, which is that there are no indicators to manage the new product development process. Thus, it explores the state of the art about Lean Product Development practices and principles, providing a definition of concepts and a framework for benchmarking to later evaluate how lean are Product Development Processes at the companies.
\end{abstract}

Keywords: product development, lean approach, practices, performance measures.

\section{Introduction}

Lean is an approach that seeks to eliminate "fat," or that is, all of the waste that causes harm to the system. The focus is on the client and the processes that add value in terms of price, deadline, quality and delivery including social and environmental criteria. The lean approach is not new. Although Japanese companies have used it since 1950, it can be seen that it came to be quite successful when it began to be treated systematically, integrating people, processes, technologies and tools.

Ward (2007) emphasized that the development and introduction of new products is essential to guarantee the sustainability of a business. Lean manufacturing and its tools are widely applied in manufacturing. Nevertheless, it does not help to have world-class lean production if the product manufactured is not what the client wants. The product development process, in addition to being able to capture the scope of what is of value to the client, is aimed at the operational and technological implications that will be found in a following moment in the manufacturing processes inside and outside of the company (DAL FORNO; FORCELLINI; PEREIRA, 2009).

Regardless of the sector in which the company operates or the type of product that it develops, some problems are common in the practice and in the literature. Waal and Counet (2009) enumerate them - managers give low priority to the implementation of performance evaluation systems, the implementation requires more time than expected, there are insufficient resources and capacity for implementation, the organization is an instable environment, there is a lack of commitment from management, there is lack of staff motivation, insufficient commitment from middle management, a lack of support from Information Technology, the organization does not have a clear understanding of its strategy, there is no learning network or departmental vision, there is difficulty in defining Critical Success Factors, a lack of focus on internal management and control, a difficulty in transforming the corporate strategy into individual objectives, difficulty in correctly defining the indicators, too much focus on results and not during the implementation process, a lack of daily accompaniment from management, a lack of leadership during coordination and implementation, difficulty in maintaining the implementation, difficulty in obtaining data for the indicators or the organization does not see the benefits of the implementation.

The lean approach can thus be understood as a way of doing more with less, given that the practices are counter measures for handling waste. This paper presents the 
state of the art of Lean Product Development. It presents a bibliographic study of periodicals from 2007 until September 2011, a classification of the most used practices, and of the indicators and improvements obtained with the application of lean product development at companies, the sectors that are most advanced, the countries with applications and other analyses and classifications. It also presents a bibliometric analysis of the literature about the concepts of Lean, Product Development, Benchmarking and synonyms, such as Lean Design, Performance Measures and their combinations. The publications were classified using various criteria.

To conduct the study of existing research, the databases ISI Web of Knowledge, CAPES portal of periodicals and Emerald Insight were used. Of the total universe, 289 articles were selected. After a reading of these articles, those which were not related to the themes were eliminated, leaving a sample to be analyzed of 247 studies.

This paper is organized as follows. The first section places in context the development of the products and the lean approach, it introduces the objectives and the methodology. Next, we present a bibliometric analysis of the studies according to the methodology used, journals that explore the issue, countries with studies and other relevant criteria. In section 3, the focus is on the practices and principles of product development, characterizing those most found and reported on by the authors.

\section{Bibliometric analysis}

An analysis of the periodicals that present the issues being studied found 75 different journals with articles about the issues, with 12 of these journals accounting for $55 \%$ of the articles selected as shown in Table 1 (DAL FORNO, 2012):

Table 1. Periodicals with the most articles about Lean Product Development (DAL FORNO, 2012).

\begin{tabular}{|l|c|}
\hline \multicolumn{1}{|c|}{ Journal } & Quantity \\
\hline $\begin{array}{l}\text { International Journal of Operations \& Production } \\
\text { Management }\end{array}$ & 27 \\
\hline Supply Chain Management: an International Journal & 20 \\
\hline Journal of Manufacturing Technology Management & 15 \\
\hline Benchmarking: an International Journal & 12 \\
\hline Industrial Management \& Data Systems & 11 \\
\hline $\begin{array}{l}\text { International Journal of Productivity and Performance } \\
\text { Management }\end{array}$ & 9 \\
\hline Business Process Management Journal & 9 \\
\hline The TQM Journal & 8 \\
\hline Journal of Product Innovation Management & 7 \\
\hline International Journal of Lean Six Sigma & 6 \\
\hline $\begin{array}{l}\text { International Journal of Physical Distribution \& } \\
\text { Logistics Management }\end{array}$ & 6 \\
\hline European Journal of Innovation Management & 6 \\
\hline
\end{tabular}

Concerning the research methodology, most of the articles (41\%) used a single or multiple case study, followed by surveys (31\%), as seen in Figure 1.

The use of the term "lean" was also verified, because there are many practices in various fields of application (manufacturing, engineering, services, logistics) although a lean approach is not always implemented in its totality in a systematic form. Thus, $77 \%$ of the studies were found to focus on a lean approach.

Another analysis concerned the sectors that most apply the lean approach for product development. Many studies have more than one application, usually because they involve multiple case studies or surveys. Some studies could not be classified because they used generic terms, such as "misc." or "various" separating companies by type (service, manufacturing), by size (small, medium, large), by position (manager, operational) or type of project (innovator, incremental).

Figure 2 reveals that the sectors of Electronics, Auto-industry, and Capital Goods are those that most apply lean practices for product development. The electronics

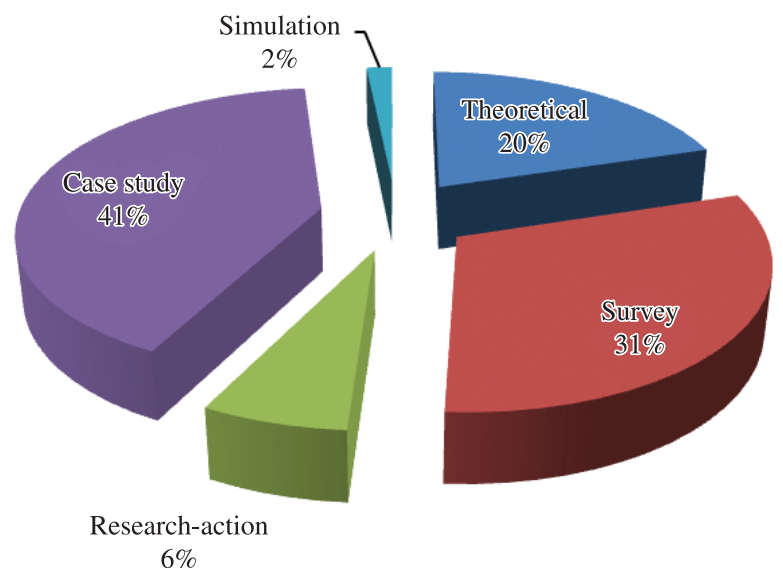

Figure 1. Methodology used in the studies analyzed (DAL FORNO, 2012).

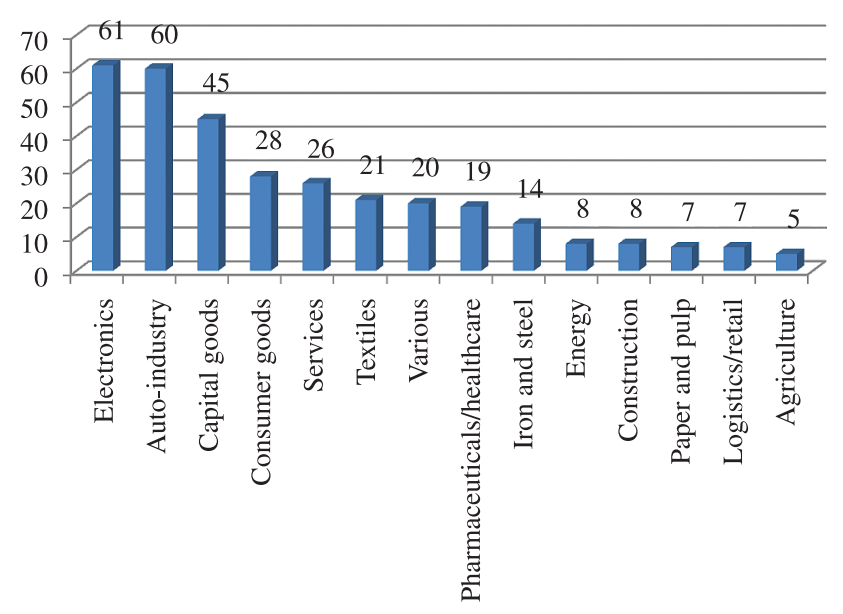

Figure 2. Number of studies by sector (DAL FORNO, 2012). 
Table 2. Conceptual map of the themes approached and their relation with the main work (DAL FORNO, 2012).

\begin{tabular}{|c|c|c|}
\hline Item & Description & Authors \\
\hline $\begin{array}{l}\text { Principles, } \\
\text { Synonyms, } \\
\text { Value }\end{array}$ & $\begin{array}{l}\text { Conducts the activities that are important from the } \\
\text { clients' perspective, assuring that the knowledge } \\
\text { is achieved on time, at the least cost, with minimal } \\
\text { changes and with a continuous flow of information } \\
\text { by the entire organization. }\end{array}$ & $\begin{array}{l}\text { Morgan and Liker (2008), Sobek (1997), Pessôa (2006), McManus, } \\
\text { Haggerty and Murman (2005), Ballé and Ballé (2005), Kennedy, } \\
\text { Harmon and Minnock (2008), Kato (2005), Seth, Seth and Goel } \\
\text { (2008), Collin, Eloranta and Holmström (2009), Hilletofth (2009), } \\
\text { Jorgensen and Emmitt (2007), Parry, Mils and Turner (2010), Fung, } \\
\text { Chen and Yip (2008), Taylor (2006), Pawar, Beltagui and Riedel } \\
\text { (2009), Allee (2009), Enquist, Edvardsson and Sebhatu (2007) and } \\
\text { Hilletofth and Eriksson (2011). }\end{array}$ \\
\hline Waste & $\begin{array}{l}\text { Elements of a process that do not add value to } \\
\text { the product such as overproduction, waiting, } \\
\text { transportation, unnecessary processes, defects, } \\
\text { reinvention, movement, stock, lack of discipline, } \\
\text { and lack of integration of information technology. }\end{array}$ & $\begin{array}{l}\text { Bauch (2004), Ward (2007), Morgan and Liker (2008), Saad and } \\
\text { Gindy (2007), Haponava and Al-Jibouri (2009), Tam, Tam and Ng } \\
\text { (2007), Cooper (2007), Ranky (2007), Yang and Su (2007), Seth, } \\
\text { Seth and Goel (2007), Singh and Garg and Sharma (2010). }\end{array}$ \\
\hline $\begin{array}{l}\text { Value Stream } \\
\text { Mapping } \\
\quad(\text { VSM })\end{array}$ & $\begin{array}{l}\text { Aims to develop a portrait of the current status to } \\
\text { visualize some wastes and calculate the lead time. } \\
\text { The improvements are planned later, in the future } \\
\text { map and in the action plan. }\end{array}$ & $\begin{array}{l}\text { Rother and Shook (2003), Locher (2008), Morgan and Liker } \\
\text { (2008), McManus, Haggerty and Murman (2005), Dal Forno, } \\
\text { Forcellini and Pereira (2009), Gurumurthy and Kodali (2009), } \\
\text { Christopher et al. (2009), Hellström and Eriksson (2008), } \\
\text { Childerhouse et al. (2010), Setijono and Dahlgaard (2007), Grant } \\
\text { and Banomyong (2010), Singh, Garg and Sharma (2010), Thomas } \\
\text { and Barton (2007), Parry, Mils and Turner (2010), Mottonen et al. } \\
\text { (2009a), Menachof, Bourlakis and Makios (2009), Trkman et al. } \\
\text { (2007), Oh and Kim (2007), Jacobs, Vickery and Droge (2007), } \\
\text { Cheng, Chen and Mao (2010), Wang, Lin and Huang (2010), } \\
\text { Haponava and Al-Jibouri (2010), Oppenheim, Murman and Secor } \\
\text { (2011), Bhasin (2011) and Chiang (2009). }\end{array}$ \\
\hline $\begin{array}{l}\text { Voice of the } \\
\text { Customer }\end{array}$ & $\begin{array}{l}\text { Practice for identifying clients' needs (QFD, Focus } \\
\text { Group, market research). }\end{array}$ & $\begin{array}{l}\text { CAR (CENTER..., 2007), Akao and Mazur (2003), Gonzalez et al., } \\
\text { (2008), McCoy, Thabet and Badinelli (2009), Carnevalli, Sassi and } \\
\text { Miguel (2004), Manion and Cherion (2009), Garrido and Pasquire } \\
\text { (2011), Afonso et al. (2008), Oppenheim, Murman and Secor (2011), } \\
\text { Gautam and Singh (2008), Ledwith, O’Dwyer and Perks (2008), } \\
\text { Cooper and Edgett (2008), Wellings, Willians and Tennant (2010), } \\
\text { Cooper and Kleinschmidt (2007) and Prajogo and Hong (2008). }\end{array}$ \\
\hline Chief Engineer & $\begin{array}{l}\text { This the heavyweight project manager, who is } \\
\text { responsible for all phases of the product project. } \\
\text { This practice is related to the type of organizational } \\
\text { arrangement, which is generally strong matrix. }\end{array}$ & $\begin{array}{l}\text { Clark and Wheelwright (1994), Morgan and Liker (2008), } \\
\text { Rozenfeld et al. (2006), Arnheiter and Greenland (2008), Holtzman } \\
\text { (2011), Sawhney et al. (2010), Owens (2007), Christopher et al. } \\
\text { (2009) and Summers and Scherpereel (2008). }\end{array}$ \\
\hline $\begin{array}{l}\text { Organizational } \\
\text { Structure }\end{array}$ & $\begin{array}{l}\text { For each type of project (incremental, innovative, } \\
\text { platform, radical or follow source), there is } \\
\text { a structure that is most suitable. For the lean } \\
\text { approach, it is suggested that for radical and } \\
\text { innovative projects the structure be of the strong } \\
\text { matrix type. Meanwhile, for incremental projects, } \\
\text { a structure by departments or function can resolve } \\
\text { the issue. }\end{array}$ & $\begin{array}{l}\text { Arnheiter and Greenland (2008), Mottonen et al. (2009a), Roh, } \\
\text { Hong and Park (2008), Morgan (2007), Karlsson and Sköld (2007), } \\
\text { Huang and Wu (2010), Visser et al.(2010), Knudsen and Mortensen } \\
\text { (2011), Bergfors and Larsson (2007), Bassani et al. (2007), } \\
\text { Kollberg, Dahlgaard and Brehmer (2007) and Oorschot et al. } \\
\text { (2010). }\end{array}$ \\
\hline $\begin{array}{c}\text { Visual } \\
\text { Management }\end{array}$ & $\begin{array}{l}\text { Measures for detecting errors at the source so they } \\
\text { do not go farther. Examples are parametric systems } \\
\text { in CAD, check lists, detailed and standardized test } \\
\text { plans. A visual framework with the schedule of the } \\
\text { dates and phases of the projects underway assists } \\
\text { visualizing compliance with deadlines and taking } \\
\text { preventive measures on time, according to the } \\
\text { frequency that project performance is checked. }\end{array}$ & $\begin{array}{l}\text { Locher (2008), Parry and Turner (2006), Childerhouse et al., } \\
\text { (2010), Quesada-Pineda and Gazo (2007), Singh, Garg and } \\
\text { Sharma (2009), Arnheiter and Greenland (2008), Ranky (2007), } \\
\text { Kumar and Antony (2008), Summers and Scherpereel (2008) and } \\
\text { Mottonen et al. (2009a). }\end{array}$ \\
\hline Project Library & $\begin{array}{l}\text { This practice resumes the learning and the habit } \\
\text { of registering the lessons learned to facilitate the } \\
\text { reuse of knowledge. }\end{array}$ & $\begin{array}{l}\text { Nonaka and Takeuchi (2008), Senge (2004), Morgan and Liker } \\
\text { (2008), Waal and Counet (2009), Prajogo and Hong (2008), Ajmal, } \\
\text { Nordström and Helo (2009), Meybodi (2009), Bilalis et al. (2007), } \\
\text { Kira and Frieling (2010), Clark (2007) and Jeong and Hong (2007). }\end{array}$ \\
\hline
\end{tabular}


Table 2. Continuation....

\begin{tabular}{|c|c|c|}
\hline Item & Description & Authors \\
\hline A3 Reports & $\begin{array}{l}\text { Practice used for problem solving, presentation } \\
\text { of proposals and for strategic planning. Expresses } \\
\text { the power of simplifying and encouraging the } \\
\text { reflection. }\end{array}$ & $\begin{array}{l}\text { May (2007), Dennis (2008), Sobek and Smaley (2010), Morgan } \\
\text { and Liker (2008), Shook (2009), Chakravorty (2009), Olivella, } \\
\text { Cuatrecasas and Gavilan (2008), Kumar and Antony (2008), Jeong } \\
\text { and Hong (2007), Johnson, Sun and Johnson (2007), Smadi (2009), } \\
\text { Singh, Garg and Sharma (2009), Lee and Peccei (2008), Waal and } \\
\text { Counet (2009), Arnheiter and Greenland (2008), Laeequddin et al. } \\
\text { (2010) and Fung, Chen and Yip (2008). }\end{array}$ \\
\hline Modularity & $\begin{array}{l}\text { Items of any nature in groups, which have } \\
\text { standardized interfaces to be used in more than } \\
\text { one product. In the automotive industry, the } \\
\text { term platform is used to represent the modular } \\
\text { development of families, which share similar } \\
\text { global functions. }\end{array}$ & $\begin{array}{l}\text { Rozenfeld et al. (2006), Walton (1999), Ulrich and Tung (1991), } \\
\text { Ro, Liker and Fixson (2007), Pekkarinen and Ulkuniemi (2008), } \\
\text { Jacobs, Vickery and Droge (2007), Ahmad, Schroeder and Mallick } \\
\text { (2010), Pero et al. (2010), Rytter, Boer and Koch (2007), Wu and } \\
\text { Park (2009), Hilletofth (2009), Pekkarinen and Ulkuniemi (2008), } \\
\text { Howard and Squire (2007), Mahmoud-Joini and Lenfle (2010), } \\
\text { Donk and Vaart (2007), Jacobs, Vickery and Droge (2007), Ahmad, } \\
\text { Schroeder and Mallick (2010), Pasche, Persson and Löfsten (2011), } \\
\text { Ranky (2007) and Bargelis, Kuosmanen and Stasiskis (2009). }\end{array}$ \\
\hline $\begin{array}{c}D F x(D F M A, \\
D F M)\end{array}$ & $\begin{array}{l}\text { This is a philosophy that seeks to facilitate } \\
\text { assembly and disassembly beginning with } \\
\text { the product design to minimize costs. Other } \\
\text { considerations are also made, such as designing } \\
\text { for the environment, services and Six Sigma. The } \\
\text { benefits are reductions in the time-to-market, } \\
\text { defects and assembly operations and calls for } \\
\text { services. }\end{array}$ & $\begin{array}{l}\text { Bargelis, Kuosmanen and Stasiskis (2009), Kincade, Regan and } \\
\text { Gibson (2007), Caputo and Pelagagge (2008), Singh, Garg and } \\
\text { Sharma (2009), Boyle and Scherrer-Rahtje (2009), Mottonen et al. } \\
\text { (2009b), Jacobs, Vickery and Droge (2007) and Kumar, Garg and } \\
\text { Garg (2009). }\end{array}$ \\
\hline $\begin{array}{c}\text { Early Supplier } \\
\text { Involvement } \\
\quad(\text { ESI) }\end{array}$ & $\begin{array}{l}\text { The intention is to maintain few suppliers } \\
\text { and involve them from the beginning of the } \\
\text { development and thus establish a long term } \\
\text { partnership. The benefits are decreased risk, } \\
\text { reduced costs and lead time, in addition to joint } \\
\text { development and establishment of joint goals. }\end{array}$ & $\begin{array}{l}\text { Gurumurthy and Kodali (2009), Salzman (2002), McAdam, Hazlett } \\
\text { and Anderson-Gillespie (2008), Magnan, Fawcett and Birou (1999), } \\
\text { Carr et al. (2008), Deros, Yusof and Salleh (2006), Ge and Fujimoto } \\
\text { (2006), Williams (2007), Srai and Gregory (2008), Du (2007), } \\
\text { Sarshar; Pitt (2009), Akesson, Jonsson and Edanius-Hällas (2007), } \\
\text { Park et al. (2010) and Shamsuzzoha, Kyllönen and Helo (2009). }\end{array}$ \\
\hline Standardization & $\begin{array}{l}\text { Standardization is the basis for reducing the } \\
\text { variables through the list of verifications and } \\
\text { as a mechanism to capture knowledge. The } \\
\text { standardization of the project involves the product, } \\
\text { its components, raw material and its architecture. } \\
\text { The standardization of processes involves common } \\
\text { tasks, sequence and duration of tasks and the } \\
\text { standardization of the technical abilities is related } \\
\text { to the abilities of the people involved in the } \\
\text { development team. }\end{array}$ & $\begin{array}{l}\text { Emiliani (2008), Muenstermann et al. (2010), Marksberry et al. } \\
\text { (2010), Wang and Kleiner (2005), Wee and Wu (2009), Gurumurthy } \\
\text { and Kodali (2009), Rytter, Boer and Koch (2007), Kincade, Regan } \\
\text { and Gibson (2007), Mohammed, Shankar and Banwet (2008), } \\
\text { Reichhart and Holweg (2007), Summers and Scherpereel (2008), } \\
\text { Grant and Banomyong (2010), Aláez-Aller and Longás-García } \\
\text { (2010) and Nunes and Bennett (2010). }\end{array}$ \\
\hline $\begin{array}{l}\text { Integration/ } \\
\text { Simultaneous } \\
\text { Engineering }\end{array}$ & $\begin{array}{l}\text { This signifies involving a multidisciplinary team } \\
\text { from the beginning of the project to meet the } \\
\text { requirements of the client at low cost. One of the } \\
\text { main benefits is anticipating the already existing } \\
\text { manufacturing and assembly problems and } \\
\text { incorporating various fields of knowledge. }\end{array}$ & $\begin{array}{l}\text { Du (2007), Kincade, Regan and Gibson (2007), Snee (2010), } \\
\text { Arnheiter and Greenland (2008), Othman and Ghani (2008), } \\
\text { Brousseau, Dimov and Setchi (2008), Tuholski et al. (2009), Saad } \\
\text { and Gindy (2007), Arnheiter and Greenland (2008), Mottonen et al. } \\
\text { (2009a), Dahlgaard-Park and Dahlgaard (2010) and Othman and } \\
\text { Ghani (2008). }\end{array}$ \\
\hline$S B C E$ & $\begin{array}{l}\text { In simultaneous engineering based on sets, each } \\
\text { member of the development team communicates } \\
\text { a set of parallel and independent alternatives } \\
\text { until during the PDP phases, the alternatives are } \\
\text { eliminated until the single best remains, generated } \\
\text { from the combination of systems, subsystems and } \\
\text { components. }\end{array}$ & $\begin{array}{l}\text { Kincade, Regan and Gibson (2007), Schäfer and Sorensen (2010), } \\
\text { Hines, Francis and Found (2006), Madhavaram and Appan (2010), } \\
\text { Salah, Rahim and Carretero (2010), Doll, Hong and Nahm (2010), } \\
\text { Mols (2010), Pêssoa, Loureiro and Alves (2007), Mottonen et al. } \\
\text { (2009b), Joh and Mayfield (2009), Chin et al. (2010), Brousseau, } \\
\text { Dimov and Setchi (2008), Gautam and Singh (2008) and Cooper } \\
\text { and Edgett (2008). }\end{array}$ \\
\hline
\end{tabular}


Table 2. Continuation....

\begin{tabular}{|c|l|l|}
\hline Item & \multicolumn{1}{|c|}{ Description } & \multicolumn{1}{c|}{ Authors } \\
\hline $\begin{array}{c}\text { Virtual } \\
\text { Simulation }\end{array}$ & $\begin{array}{l}\text { To conduct virtual simulation through digital } \\
\text { It is important for forecasting errors and interacting } \\
\text { with the process, thus reducing costs of physical } \\
\text { prototypes and time. }\end{array}$ & $\begin{array}{l}\text { Ettlie and Elsenbach (2007), Fox et al. (2009), Sarkis, Talluri and } \\
\text { Gunasekaran (2007), Bargelis, Kuosmanen and Stasiškis (2009), } \\
\text { Saliba, Zarg and Borg (2010), Muglestone et al. (2008), Björnfot } \\
\text { and Jongeling (2007), Grant and Banomyong (2010), Caputo and } \\
\text { Pelagagge (2008), Reinsertsen (2007), Catalano et al. (2009), } \\
\text { Linton and Walsh (2008) and Durmusogiu (2009). }\end{array}$ \\
\hline $\begin{array}{c}\text { Deployment } \\
\text { Strategy }\end{array}$ & $\begin{array}{l}\text { The corporate strategy is defined and broken down } \\
\text { into individual objectives. Also called hoshin kanri, } \\
\text { it is designed for the use of collective thinking to } \\
\text { improve an organization's objectives in an aligned } \\
\text { manner and with everyone's participation. }\end{array}$ & $\begin{array}{l}\text { Sarshar and Pitt (2009), Gehlhar et al. (2009), Larsson, Arif and } \\
\text { (2008), Parry, Milk and Turner (2010), Hofmann (2010), Taylor and } \\
\text { Taylor (2008), Kaipia and Holmström (2007), Noori et al (2009), } \\
\text { Byrne, Lubowe and Blitz (2007) and Wouters (2009). }\end{array}$ \\
\hline $\begin{array}{c}\text { Kaizen/ } \\
\text { Improvement }\end{array}$ & $\begin{array}{l}\text { This signifies improving continuously in a short } \\
\text { space of time or at low cost, supported by a team } \\
\text { brought together to achieve goals. It is based on } \\
\text { PDCA and quality. }\end{array}$ & $\begin{array}{l}\text { Smadi (2009), Taylor and Taylor (2008), Aoki (2008) and } \\
\text { Badurdeen, Wijekoon and Marksberry (2011). }\end{array}$ \\
\hline $\begin{array}{c}\text { Performance } \\
\text { Evaluation via } \\
\text { Benchmarking }\end{array}$ & $\begin{array}{l}\text { A continuous and systematic process to evaluate } \\
\text { products, services and work processes at } \\
\text { organizations that are recognized as representative } \\
\text { of the best practices, with the goal of } \\
\text { organizational improvement. }\end{array}$ & $\begin{array}{l}\text { Christian-Carter (2002), Spendolini (1993), Camp (1989), Anand } \\
\text { and Kodali, (2008), Waal and Counet (2009), Meybodi (2009), } \\
\text { Miguel and Andrietta (2009), Huq, Abbo and Huq (2008), } \\
\text { Gurumurthy and Kodali (2009), Quesada-Pineda and Gazo (2007), } \\
\text { Sharma and Kodali (2008), Mottonen et al. (2009a) and Moffett, } \\
\text { Anderson-Gillespie and McAdam (2008). }\end{array}$ \\
\hline
\end{tabular}

sector encompasses electrical appliances, motors and alternators, telecommunications devices, semiconductors, photographic equipment, computers watches and air conditioning. The auto-industry includes companies in the manufacturing sectors of weapons, automobiles, trucks, aerospace, automotive components, bicycles and airplanes. In the capital goods sector practical applications were found at companies that manufacture valves and solenoids, injected and molded plastics, rubber and machinery. These three sectors represent $50 \%$ of the sectors applied - electronics, $(19 \%)$, auto-industry (18\%) and capital goods (14\%).

Concerning the location of the application, there were a total of 44. In addition to identification by country, applications that mentioned the continent were also included, such as Europe, North America, Asia and Africa. The country with the highest number of applications was the United States (18\%), followed by the United Kingdom $(15 \%)$, Sweden (7\%), China (6\%) and India (4\%). Studies in Germany, Italy and Finland were each identified in publications, or $4 \%$ for each of them.

In terms of the year of publication, the most current were considered (from 2007 until August of 2011). Using as an example the Emerald Insight database, in which a search was conducted of the periodicals, Figure 3 shows that the theme has received increased attention, and is considered current and relevant among academics. In this period, there was a $35 \%$ increase in publications, an average of $10 \%$ per year.

\section{Lean product development principles and practices}

Before detailing the practices, it should be defined that "best practices" are those that have been shown to produce

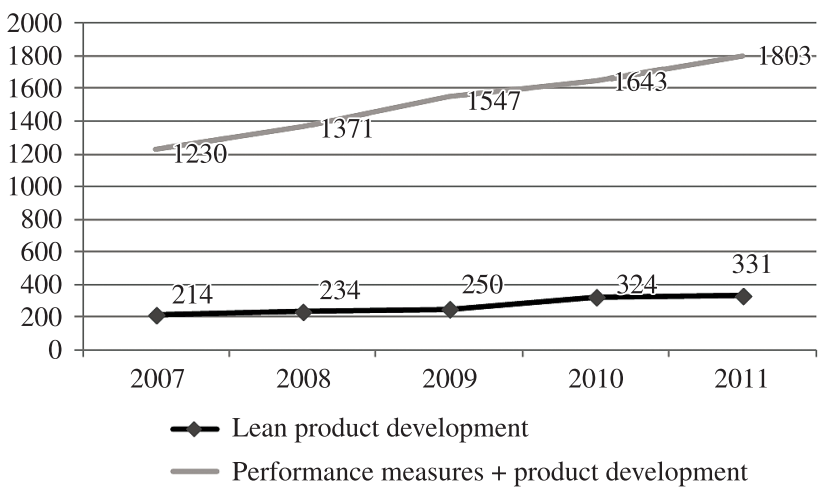

Figure 3. Growth in articles in academic journals from 2007 to 2011 (DAL FORNO, 2012).

better results, selected by a systematic process, judged to be exemplary, good or successful (EFQM Benchmarking Manager apud JARRAR; ZAIRI, 2000).

In summary, good practices are techniques, methodologies, procedures or processes that were implemented and improve the results of a business for an organization, satisfying the needs of clients and interested parties. Meanwhile, a "best practice" is that which was proven to be the best approach by many organizations, based on the analysis of performance data for the process (JARRAR; ZAIRI, 2000).

This study will use the term "practices" as a synonym for "best practices." Table 2 defines some key terms used in this study related to the practices and principles of Lean Product Development. 
Table 3. Lean Product Development Practices used in the publications analyzed (DAL FORNO, 2012).

\begin{tabular}{|c|c|c|}
\hline Practice & Qty & \% \\
\hline Simultaneous Engineering/ Integration & 94 & 12 \\
\hline Chief Engineer & 60 & 7 \\
\hline ESI & 99 & 12 \\
\hline Structural Organization & 46 & 6 \\
\hline Visual Management & 31 & 4 \\
\hline Modularity & 62 & 8 \\
\hline Standardization & 111 & 14 \\
\hline Learning network & 103 & 13 \\
\hline SBCE & 12 & 1 \\
\hline Virtual Simulation & 35 & 4 \\
\hline VOC & 116 & 14 \\
\hline VSM & 39 & 5 \\
\hline Total & 808 & 100 \\
\hline
\end{tabular}

One of the main objectives of the classification of the studies was to identify which lean practices of the PDP were used, the indicators and the results. Table 3 thus highlights the most used practices considering that, many times, more than one was found in each study. Integration, Early Supplier Involvement, Standardization, Learning and the Voice of the Customer were the five practices that were most found. Later, these practices were explored in terms of concepts and results obtained with their introduction of PDP.

\section{Conclusions}

The lean approach has been a good alternative for improving product development processes to reduce time-to-market and deliver a product of value to the client. Many companies already use the practices in manufacturing and are expanding them to other areas of the company. Nevertheless, much still needs to be done because it is realized that the lean approach goes beyond the implementation of practices. An understanding of the principles and a visualization of the whole is needed, so that product development is visualized as a system that adds internal and external value. No company is totally lean or totally not lean. Even if the approach is not applied as a whole, some practices are initiated directly or indirectly.

The purpose of this paper was to explore the state of the art about product development, performance evaluation, the lean approach and their interfaces. The studies were evaluated with the main criteria of identifying the existing practices, the results that are being obtained with the introduction of lean product development, indicators that are being used and how this process is inserted in organizations.

Even with a large universe of studies explored since 2007 (nearly 300 articles), the gaps in the research are evident, that is, there are no clear metrics defined in a quantitative manner to diagnose PDP in the various industrial sectors.
Thus, future studies are being undertaken to organize a diagnostic method via benchmarking to evaluate the degree of lean PDP at companies.

\section{Acknowledgements}

The authors thank to CAPES for finantial support.

\section{References}

AFONSO, P. et al. The influence of time-to-market and target costing in the new product development success. International Journal Production Economics, v. 115 , p. 559-568, 2008. http://dx.doi.org/10.1016/j. ijpe.2008.07.003

AKAO, Y.; MAZUR, G. H. The leading edge in QFD: past, present and future. International Journal of Quality \& Reliability Management, v. 20, n. 1, p. 20-35, 2003. http:// dx.doi.org/10.1108/02656710310453791

AKESSON, J.; JONSSON, P.; EDANIUS-HÄLLAS, R. An assessment of sourcing strategies in the Swedish apparel industry. International Journal of Physical Distribution \& Logistics Management, v. 37, n. 9, p. 740-762, 2007. http://dx.doi.org/10.1108/09600030710840840

AHMAD, S.; SCHROEDER, R. G.; MALLICK, D. $\mathrm{N}$. The relationship among modularity, functional coordination, and mass customization - Implications for competitiveness. European Journal of Innovation Management, v. 13, n. 1, p. 46-61, 2010. http://dx.doi. org/10.1108/14601061011013221

AJMAL, M. M.; NORDSTRÖM, F.; HELO, P. Assessing the effectiveness of business consulting in operations development projects. International Journal of Productivity and Performance Management, v. 58, n. 6, p. 523-541, 2009. http://dx.doi.org/10.1108/17410400910977073

ALLEE, V. Value-creating networks - organizational issues and challenges. The Learning Organization, v. 16, n. 6, p. 427-442, 2009. http://dx.doi. org/10.1108/09696470910993918

ANAND, G.; KODALI, R. Benchmarking the benchmarking models. Benchmarking: an International Journal, v. 15, n. 3, p. 257-291, 2008.

AOKI, K. Transferring Japanese kaizen activities to overseas plants in China. International Journal of Operations \& Production Management, v. 28, n. 6, p. 518-539, 2008. http://dx.doi.org/10.1108/01443570810875340

ARNHEITER, E. D.; GREENLAND, J. E. Looking for root cause - a comparative analysis. The TQM Journal, v. 20, n. 1, p. 18-30, 2008. http://dx.doi. org/10.1108/09544780810842875

BADURDEEN, F.; WIJEKOON, K.; MARKSBERRY, P. An analytical hierarchy process-based tool to evaluate value systems for Lean transformations. Journal of Manufacturing 
Technology Management, v. 22, n. 1, p. 46-65, 2011. http:// dx.doi.org/10.1108/17410381111099806

BALlÉ, F.; BALLÉ, M. Lean Development. Business Strategy Review, v. 16, n. 3, p. 17-22, 2005. http://dx.doi. org/10.1111/j.0955-6419.2005.00369.x

BARGELIS, A.; KUOSMANEN, P.; STASIŠKIS, A. Inteligent Interface Module of Process Capability among Product and Process Development Systems in Virtual Enviroment. Journal of Mechanical Engineering, v. 55, p. 1-9, 2009.

BASSANI, C. et al. Measuring performance in R\&NPD: The case of Whitehead Alenia Sistemi Subacquei - a Finmeccanica company. European Journal of Innovation Management, v. 13, n. 4, p. 481-506, 2010. http://dx.doi. org/10.1108/14601061011086302

BAUCH, C. Lean Product Development: making waste transparent. 2004. Thesis (Doctorate in Mechanical Engineering)-Massachusetts Institute of Technology, Massachusetts, 2004.

BERGFORS, M. E.; LARSSON, A. Product and process innovation in process industry: a new perspective on development. Journal of Strategy and Management, v. 2, n. 3, p. 261- 276, 2009. http://dx.doi. org/10.1108/17554250910982499

BHASIN, S. Measuring the Leanness of an organization. International Journal of Lean Six Sigma, v. 2, n. 1, p. 55-74, 2011. http://dx.doi. org/10.1108/20401461111119459

BILALIS, N. et al. Benchmarking the competitiveness of industrial sectors - application in textiles. International Journal of Productivity and Performance Management, v. 56, n. 7, p. 603-622, 2007. http://dx.doi. org/10.1108/17410400710823642

BJÖRNFOT, A.; JONGELING, R. Application of line-of-balance and 4D CAD for lean planning. Construction Innovation, v. 7, n. 2, p. 200-211, 2007. http://dx.doi. org/10.1108/14714170710738559

BOYLE, T. A.; SCHERRER-RATHJE, M. An empirical examination of the best practices to ensure manufacturing flexibility: lean alignment. Journal of Manufacturing Technology Management, v. 20, n. 3, p. 348-366, 2009. http://dx.doi.org/10.1108/17410380910936792

BROUSSEAU, E.; DIMOV, S.; SETCHI, R. Knowledge acquisition techniques for feature recognition in CAD models. Journal of Intelligent Manufacturing, v. 19, p. 21-32, 2008. http://dx.doi.org/10.1007/s10845-007-0043-7

BYRNE, G.; LUBOWE, D.; BLITZ, A. Using a Lean Six Sigma approach to drive innovation. Strategy \& Leadership, v. 35, n. 2, p. 5-10, 2007. http://dx.doi. org/10.1108/10878570710734480
CAMP, R. C. Benchmarking - o caminho da qualidade total. Tradução de Nivaldo Montingelli Junior. São Paulo: Pioneira Thomson Learning, 1989.

CAPUTO, A. C.; PELAGAGGE, P. M. Effects of product design on assembly lines performances. Industrial Management \& Data Systems, v. 108 , n. 6, p. 726-749, 2008. http:// dx.doi.org/10.1108/02635570810883987

CARNEVAlli, J. A.; SASSI, A. C; MIGUEL, P. A. C. Aplicação do QFD no desenvolvimento de produtos: levantamento sobre seu uso e perspectivas para pesquisas futuras. Gestão \& Produção, v. 11, n. 1, p. 33-49, 2004. http://dx.doi.org/10.1590/S0104-530X2004000100004

CARR, A. S. et al. Supplier dependence - impact on supplier's participation and performance. International Journal of Operations \& Production Management, v. 28, n. 9, p. 899916, 2008. http://dx.doi.org/10.1108/01443570810895302

CATALANO, C. E. et al. A Product Design Ontology for Enhancing shape processing in design workflows. Journal of Intelligent Manufacturing, v. 20, p. 553-567, 2009. http://dx.doi.org/10.1007/s10845-008-0151-z

CENTER FOR AUTOMOTIVE INDUSTRY - CAR. How automakers plan their products. Business Planing, 2007. Disponível em: <www.cargroup.org>. Acesso em: 07 set. 2010.

CHAKRAVORTY, S. S. Process Improvement: using Toyota's A3 Reports. Quality Management Journal, v. 16, n. 4, p. 7-26, 2009.

CHENG, H.; CHEN, M.; MAO, C. The evolutionary process and collaboration in supply chains. Industrial Management \& Data Systems, v. 110, n. 3, p. 453-474, 2010. http:// dx.doi.org/10.1108/02635571011030079

CHIANG, T. The minimum cost PD process planning and control methodology with the consideration of resourcetime constraints and skill levels. Concurrent Engineering, v. 17, n. 4, p. 257-266, 2009. http://dx.doi. org/10.1177/1063293X09352121

CHILDERHOUSE, P. et al. Auditing improvements in a product delivery process (AIPDP). Business Process Management Journal, v. 16, n. 4, p. 598-618, 2010. http:// dx.doi.org/10.1108/14637151011065937

CHIN, K. et al. An Evidencial-Reasoning-Interval-Based Method for New Product Design Assessment. IEEE Transactions on Engineering Management, v. 56, n. 1, p. 142-156, 2009. http://dx.doi.org/10.1109/ TEM.2008.2009792

CHRISTIAN-CARTER, J. The role of benchmarking in the provision of management development programmes. British Journal of Educational Technology, v. 33, n. 1, p. 77-87, 2002. http://dx.doi.org/10.1111/1467-8535.00240 
CHRISTOPHER, M. et al. Value stream classification. Journal of Manufacturing Technology Management, v. 20, n. 4, p. 460-474, 2009. http://dx.doi. org/10.1108/17410380910953720

CLARK, E. E. Characteristics of work organization in UK and Philippine call centers. Team Performance Management, v. 13, n. 7-8, p. 227-243, 2007. http://dx.doi. org/10.1108/13527590710842547

CLARK, K. B.; WHEELWRIGHT, S. C. The product development change: competing through speed, quality and creativity. Harvard Business Review Book, 1994.

COLlin, J.; ELORANTA, E.; HOLMSTRÖM, J. How to design the right supply chains for your customers. Supply Chain Management: an International Journal, v. 14, n. 6, p. 411-417, 2009. http://dx.doi. org/10.1108/13598540910995174

COOPER, R. Seven "principles" of innovation - A lack of focus. Strategic Direction, v. 23, n. 1, p. 38-40, 2007. http:// dx.doi.org/10.1108/02580540710716608

COOPER, R. G.; EDGETT, S. J. Maximizing Productivity in Product Innovation. Research Technology Management, v. 51, n. 2, p. 1-20, 2008.

COOPER, R. G.; KLEINSCHMIDT, E. J. Winning business in product development - the critical success factors. Research Technology Management, v. 39, n. 4, p. 18-29, 2007.

DAHLGAARD-PARK, S. M.; DAHLGAARD, J. J. Organizational learnability and innovability. International Journal of Quality and Service Sciences, v. 2, n. 2, p. 153-174, 2010. http://dx.doi. org/10.1108/17566691011057339

DAL FORNO, A. J. Método de avaliação via benchmarking do processo do desenvolvimento enxuto de produtos. 2012. 302 f. Tese (Doutorado em Engenharia de Produção)-Universidade Federal de Santa Catarina, Florianópolis, 2012.

DAL FORNO, A. J.; FORCELLINI, F. A.; PEREIRA, F. A. Um procedimento simples para evitar as causas dos desperdícios nas tarefas do PDP. In: CONGRESSO BRASILEIRO DE DESENVOLVIMENTO DE PRODUTO - CBGDP, 7., 2009, São José dos Campos. Anais... São José dos Campos, 2009.

DENNIS, P. Produção Lean Simplificada. Porto Alegre: Bookman, 2008.

DEROS, B. M.; YUSOF, S. M.; SALLEH, A. M. A benchmarking implementation framework for automotive manufacturing SMEs. Benchmarking: an International Journal, v. 13, n. 4, p. 396-430, 2006.

DOLL, W. J.; HONG, P.; NAHM, A. Antecedents and outcomes of manufacturability in integrated product development. International Journal of Operations e Production
Management, v. 30, n. 8, p. 821-852, 2010. http://dx.doi. org/10.1108/01443571011068180

DONK, D. P.; VAART, V. Responsiveness through buyer-focused cells - exploring a new pupply strategy. International Journal of Operations \& Production Management, v. 27, n. 12, p. 1362-1379, 2007. http:// dx.doi.org/10.1108/01443570710835651

DU, L. Acquiring competitive advantage in industry through supply chain integration - a case study of Yue Yuen Industrial Holdings Ltd. Journal of Enterprise Information Management, v. 20, n. 5, 2007, p. 527- 543. http://dx.doi. org/10.1108/17410390710823680

DURMUSOGIU, S. S. The role of top management team's information technology (IT) infrastructure view on new product development - Conceptualizing IT infrastructure capability as a mediator. European Journal of Innovation Management, v. 12, n. 3, 2009, p. 364-385. http://dx.doi. org/10.1108/14601060910974237

ENQUIST, B.; EDVARDSSON, B.; SEBHATU, S. P. Values-based service quality for sustainable business. Managing Service Quality, v. 17, n. 4, p. 385-403, 2007. http://dx.doi.org/10.1108/09604520710760535

ETTLIE, J. E.; ELSENBACH, J. M. Modified Stage-Gates Regimes in New Product Development. Journal of Product Innovation Management, v. 24, p. 20-33. http://dx.doi. org/10.1111/j.1540-5885.2006.00230.x

FOX, S. et al. Formulation of robust strategies for project manufacturing business. International Journal of Managing Projects in Business, v. 2, n. 2, p. 217-237, 2009. http://dx.doi.org/10.1108/17538370910949275

FUNG, P. K. O.; CHEN, J. S. N.; YIP, L. S. C. Relatioships and performance of trade intermediaries - an exploratory study. European Journal of Marketing, v. 41, n. 1-2, p. 159-180, 2007. http://dx.doi. org/10.1108/03090560710718166

GARRIDO, J. S.; PASQUIRE, C. Value theory in lean construction. Journal of Financial Management of Property and Construction, v. 16, n. 1, p. 8-18, 2011. http://dx.doi.org/10.1108/13664381111116043

GAUTAM, N.; SINGH, N. Lean Product Development Maximizing the customer perceived value through design change (redesign). International Journal Production Economics, v. 114, p. 313-332, 2008. http://dx.doi. org/10.1016/j.ijpe.2006.12.070

GE, D.; FUJIMOTO, T. Suppliers' Involvement in New Product Development in the Japanese Auto Industry - A Case Study from a Product Architecture Perspective. In: HERSTATT, C. et al. (Orgs.). Management of Technology e Management in Japan. Springer, 2006. cap. 11, p. 235-248. 
GEHLHAR, M. J. et al. Brand leadership and product innovation as firm strategies in global food markets. Journal of Product \& Brand Management, v. 18, n. 2, p. 115-126, 2009. http:// dx.doi.org/10.1108/10610420910949013

GONZALEZ, M. E. et al. Designing a supply chain management academic curriculum using QFD and benchmarking. Quality Assurance in Education, v. 16, n. 1, p. 36-60, 2008. http:// dx.doi.org/10.1108/09684880810848404

GRANT, D. B.; BANOMYONG, R. Design of closed-loop supply chain and product recovery management for fast-moving consumer goods. Asia Pacific Journal of Marketing and Logistics, v. 22, n. 2, p. 232-246, 2010. http://dx.doi.org/10.1108/13555851011026971

GURUMURTHY, A.; KODALI, R. Application of benchmarking for assessing the lean manufacturing implementation. Benchmarking: an International Journal, v. 16, n. 2, p. 274-308, 2009.

HAPONAVA, T.; AL-JIBOURI, S. Identifying key performance indicators for use in control of pre-project stage process in construction. International Journal of Productivity and Performance Management, v. 58, n. 2, p. 160-173, 2009. http://dx.doi.org/10.1108/17410400910928743

HELLSTRÖM, A.; ERIKSSON, H. Are you viewing, mapping or managing your processes?. The TQM Journal, v. 20, n. 2, p. 166-174, 2008. http://dx.doi. org/10.1108/17542730810857390

HILLETOFTH, P. How to develop a differentiated supply chain strategy. Industrial Management \& Data Systems, v. 109, n. 1, p. 16-33, 2009. http://dx.doi. org/10.1108/02635570910926573

HILLETOFTH, P.; ERIKSSON, D. Coordinating New Product Development with Supply Chain Management. Industrial Management \& Data Systems, v. 111, n. 2, p. 264-281, 2011. http://dx.doi.org/10.1108/02635571111115173

HINES, P.; FRANCIS, M.; FOUND, P. Towards lean product lifecycle management: a framework for new product development. Journal of Manufacturing Technology Management, v. 17, n. 7, p. 866-887, 2006. http://dx.doi. org/10.1108/17410380610688214

HOFMANN, E. Linking corporate strategy and supply chain management. International Journal of Physical Distribution \& Logistics Management, v. 40, n. 4, p. 256-276, 2010. http://dx.doi.org/10.1108/09600031011045299

HOLTZMAN, Y. Strategic research and development: it is more than just getting the next product to market. Journal of Management Development, v. 30, n. 1, p. 126-133, 2011. http://dx.doi.org/10.1108/02621711111098424

HOWARD, M.; SQUIRE, B. Modularization and the impact on supply relationships. International Journal of Operations \&
Production Management, v. 27, n. 11, p. 1192-1212, 2007. http://dx.doi.org/10.1108/01443570710830593

HUANG, Y. C.; WU, Y. C. J. The effects of organizational factors on green new product success Evidence from high-tech industries in Taiwan. Management Decision, v. 48, n. 10, p. 1539-1567, 2010. http://dx.doi. org/10.1108/00251741011090324

HUQ, F.; ABBO, M. H.; HUQ, Z. Perceptions about benchmarking best practices among French managers - an exploratory survey. Benchmarking: an International Journal, v. 15, n. 4, p. 382-401, 2008.

JACOBS, M.; VICKERY, S. K.; DROGE, G. The effects of product modularity on competitive performance - Do integration strategies mediate the relationship?. International Journal of Operations \& Production Management, v. 27, n. 10, p. 1046-1068, 2010. http:// dx.doi.org/10.1108/01443570710820620

JARRAR, Y. F.; ZAIRI, M. Internal transfer of best practice for performance excellence: a global survey. Benchmarking: an International Journal, v. 7, n. 4, p. 239-246, 2000.

JEONG, J. S.; HONG, P. Customer orientation and performance outcomes in supply chain management. Journal of Enterprise Information Management, v. 20, n. 5, p. 578-594, 2007. http://dx.doi.org/10.1108/17410390710823707

JOH, J. M.; MAYFIELD, M. The discipline of product discovery - identifying breakthrough business opportunities. Journal of Business Strategy, v. 30, n. 2-3, p. 70-77, 2009. http://dx.doi.org/10.1108/02756660910942481

JOHNSON, D. M.; SUN, J.; JOHNSON, M. A. Integrating multiple manufacturing initiatives - challenge for automotive suppliers. Measuring Business Excelence, v. 11, n. 3, p. 41-56, 2007. http://dx.doi. org/10.1108/13683040710820746

JORGENSEN, B.; EMMITT, S. Investigating the integration of design and construction from a lean perspective. Construction Innovation, v. 9, n. 2, p. 225-240, 2009. http://dx.doi.org/10.1108/14714170910950849

KAIPIA, R.; HOLMSTRÖM, J. Selecting the right planning approach for a product. Supply Chain Management: An International Journal, v. 12, n. 1, p. 3-13, 2007. http:// dx.doi.org/10.1108/13598540710724347

KARLSSON, C.; SKÖLD, M. The manufacturing extraprise - an emerging production network paradigm. Journal of Manufacturing Technology Management, v. 18, n. 8, p. 912-932, 2007. http://dx.doi. org/10.1108/17410380710828253

KATO, J. Development of a Process for Continuous Creation of Lean Value in Product Development Organizations. 2005. 206 f. Dissertação (Mestrado 
em Engenharia mecânica)-Massachusetts Institute of Technology, Massachusetts, 2005.

KENNEDY, M.; HARMON, K.; MINNOCK, E. Ready, set, dominate: implement Toyota's set-based learning for developing products and nobody can catch you. Estados Unidos: Oaklea Press, 2008.

KINCADE, D. H.; REGAN, C.; GIBSON, F. Y. Concurrent engineering for product development in mass customization for the apparel industry. International Journal of Operations \& Production Management, v. 27, n. 6, p. 627-649, 2007. http://dx.doi.org/10.1108/01443570710750295

KIRA, M.; FRIELING, E. Bureaucratic boundaries for collective learning in industrial work. Journal of Workplace Learning, v. 19, n. 5, p. 296-310, 2010. http:// dx.doi.org/10.1108/13665620710757851

KNUDSEN, M. P.; MORTENSEN, T. B. Some immediate-but negative - effects of openness on product development performance. Technovation, v. 31, p. 54-64, 2011. http:// dx.doi.org/10.1016/j.technovation.2010.07.002

KOLLBERG, B.; DAHLGAARD, J. J.; BREHMER, P. Measuring lean initiatives in health care services: issues and findings. International Journal of Productivity and Performance Management, v. 56, n. 1, p. 7-24, 2007. http:// dx.doi.org/10.1108/17410400710717064

KUMAR, M.; ANTONY, J. Comparing the quality management practices in UK SMEs. Industrial Management \& Data Systems, v. 108, n. 9, p. 1153-1166, 2008. http://dx.doi. org/10.1108/02635570810914865

KUMAR, R.; GARG, D.; GARG, T. K. Total quality management in Indian industries: relevance, analysis and directions. The TQM Journal, v. 21, n. 6, p. 607-622, 2009. http://dx.doi.org/10.1108/17542730910995873

LAEEQUDDIN, M. et al. Measuring trust in supply chain partners' relationships. Measuring Business Excellence, v. 14, n. 3, p. 53-69, 2010. http://dx.doi. org/10.1108/13683041011074218

LARSSON, M.; ARIF, M.; ABURAS, H. M. Incremental changes and efficiency leaps in the improvement of internal effectiveness. Management Research News, v. 31, n. 8, p. 583-594, 2008. http://dx.doi. org/10.1108/01409170810892145

LEDWITH, J.; O'DWYER, A.; PERKS, H. Market Orientation, NPD performance and organization performance in small firms. Journal of Product Innovation Management, v. 14, n. 2, p. 227-251, 2011.

LEE, J.; PECCEI, R. Lean production and quality commitment - a comparative study of two Korean auto firms. Personnel Review, v. 37, n. 1, p. 5-25, 2008. http:// dx.doi.org/10.1108/00483480810839941
LINTON, J. D.; WALSH, S. T. Acceleration and Extension of Opportunity Recognition for Nanotechnologies and Other Emerging Technologies. International Small Business Journal, v. 26, n. 1, p. 83-99, 2008. http://dx.doi. org/10.1177/0266242607084660

LOCHER, D. A. Value Stream Mapping for Lean Development - a how-to guide for streamlining time to market. Estados Unidos: CRC Press, 2008.

MAGNAN, G. M.; FAWCETT, S. E.; BIROU, L. M. Benchmarking manufacturing practice using the life cycle. Benchmarking: an International Journal, v. 6, n. 3, p. 239-253, 1999.

MAHMOUD-JOINI, S. B.; LENFLE, S. Platform re-use lessons from in automotive industry. International Journal of Operations \& Production Management, v. 30, n. 1, p. 98-124, 2010. http://dx.doi. org/10.1108/01443571011012398

MANION, M. T.; CHERION, J. Impact of strategic type on success measures for product development projects. Journal of Product Innovation Management, v. 26, p. 71-85, 2009. http://dx.doi.org/10.1111/j.1540-5885.2009.00335.x

MAY, M. E. Toyota: a fórmula da inovação. 4. ed. Tradução de Bruno Alexander. Rio de Janeiro: Elsevier, 2007.

McADAM, R.; HAZLETT, S.; ANDERSON-GILLESPIE, K. Developing a conceptual model of lead performance measurement and benchmarking. A multiple case analysis. International Journal of Operations \& Production Management, v. 28, n. 12, p. 1153-1185, 2008. http:// dx.doi.org/10.1108/01443570810919350

McCOY, A.; THABET, W.; BADINELLI, R. Understanding the role of developers/builders in the concurrent commercialization of product innovation. European Journal of Innovation Management, v. 12, n. 1, p. 102-128, 2009. http://dx.doi.org/10.1108/14601060910928193

McMANUS, H.; HAGGERTY, A.; MURMAN, E. Lean engineering: doing the right thing right. In: INTERNATIONAL CONFERENCE ON INNOVATION AND INTEGRATION IN AEROSPACE SCIENCES, 1. 2005, Belfast. Proceedings... Belfast, 2005.

MENACHOF, D. A.; BOURLAKIS, M. A.; MAKIOS, T. Order lead-time of grocery retailers in UK and Greek markets. Supply Chain Management: an International Journal, v. 14, n. 5, p. 349-358, 2009. http://dx.doi. org/10.1108/13598540910980260

MEYBODI, M. Z. Benchmarking performance measures in traditional and just in time companies. Benchmarking: an International Journal, v. 16, n. 1, p. 88-102, 2009.

MIGUEL, P. A. C.; ANDRIETTA, J. M. Benchmarking Six Sigma application in Brazil - Best practices in the use of 
the methodology. Benchmarking: an International Journal, v. 16, n. 1, p. 124-134, 2009.

MOFFETT, S.; ANDERSON-GILLESPIE, K.; McADAM, R. Benchmarking and performance measurement - a statistical analysis. Benchmarking: an International Journal, v. 15, n. 4, p. 368-381, 2008.

MOLS, N. P. How does concurrent sourcing affect performance?. Journal of Business e Industrial Marketing, v. 25, n. 7, p. 525-534, 2010. http://dx.doi. org/10.1108/08858621011077754

MORGAN, C. Supply network performance measurement - future challenges?. The Internatinal Journal of Logistics Management, v. 18, n. 2, p. 255-273, 2007. http://dx.doi.org/10.1108/09574090710816968

MORGAN, J.; LIKER, J. K. Sistema Toyota de desenvolvimento de produto: integrando pessoas, processo e tecnologia. Tradução de Raul Rubenich. Porto Alegre: Bookman, 2008.

MOTTONEN, M. et al. Managing requirements in ICT companies. Business Process Management Journal, v. 15, n. 6, p. 968-989, 2009a. http://dx.doi. org/10.1108/14637150911003810

MOTTONEN, M. et al. Managerial view on design for manufacturing. Industrial Management \& Data Systems, v. 109, n. 6, p. 859-872, 2009b. http://dx.doi. org/10.1108/02635570910968081

MUGLESTONE, M. et al. Accelerating the improvement process. Clinical Governance: an International Journal, v. 13, n. 1, 2008.

NAIR, A.; BOULTON, W. R. Innovation-oriented operations strategy typology and stage-based model. International Journal of Operations \& Production Management, v. 28, n. 8, p. 748-771, 2008. http://dx.doi. org/10.1108/01443570810888599

NONAKA, I., TAKEUCHI, H. Gestão do Conhecimento. Porto Alegre: Bookman, 2008.

NOORI, S. et al. The presentation of a network model for the development of innovation in R\&D centers. Journal of Chinese Entrepreneurship, v. 1, n. 2, p. 121-135, 2009. http://dx.doi.org/10.1108/17561390910956288

$\mathrm{OH}, \mathrm{H}$; KIM, E. Strategic planning for the US textile industry in the post-quota era - Achieving speed-to-market advantages with DR-CAFTA countries. Journal of Fashion Marketing and Management, v. 11, n. 2, p. 246-269, 2007. http://dx.doi.org/10.1108/13612020710751419

OliVEllA, J.; CUATRECASAS, L.; GAVILAN, N. Work organisation practices for lean production. Journal of Manufacturing Technology Management, v. 19, n. 7, p. 798-811, 2008. http://dx.doi. org/10.1108/17410380810898750
OORSCHOT, K. et al. Get fat fast Surviving Stage-Gate in NPD. Journal of Product Innovation Management, v. 27, p. 828-839, 2010. http://dx.doi.org/10.1111/ j.1540-5885.2010.00754.x

OPPENHEIM, B. W.; MURMAN, E. M.; SECOR, D. A. Lean Enablers for Systems Engineering. Systems Engineering, v. 14, n. 1, p. 29-55, 2011. http://dx.doi.org/10.1002/ sys. 20161

OTHMAN, R.; GHANI, R. A. Supply chain management and supplier's HRM practice. Supply Chain Management: an International Journal, v. 13, n. 4, p. 259-262, 2008. http:// dx.doi.org/10.1108/13598540810882143

OWENS,J.D. Why do someUKSMEs stillfind theimplementation of a new product development process problematical?. Management Decision, v. 45, n. 2, p. 235-251, 2007. http:// dx.doi.org/10.1108/00251740710727269

PARK, J. et al. An integrative framework for supplier relationship management. Industrial Management \& Data Systems, v. 110, n. 4, p. 495-515, 2010. http://dx.doi. org/10.1108/02635571011038990

PARRY, G.; MILS, J.; TURNER, C. Lean competence - integration of theories in operations management practice. Supply Chain Management: an International Journal, v. 15, n. 3, p. 216-226, 2010. http:// dx.doi.org/10.1108/13598541011039974

PARRY, G., TURNER, C. E. Application of lean visual process management tools. Production Planning and Control, v. 17, n. 1, p. 77-86, 2006. http://dx.doi. org/10.1080/09537280500414991

PASCHE, M.; PERSSON, M.; LÖFSTEN, H. Effects of platforms on new product development projects. International Journal of Operations \& Production Management, v. 31, n. 11, p. 1144-116, 2011. http://dx.doi. org/10.1108/01443571111178475

PAWAR, K. S.; BELTAGUI, A.; RIEDEL, J. C. K. H. The PSO triangle designing product, service and organisation to create value International. Journal of Operations \& Production Management, v. 29, n. 5, p. 468-493, 2009. http://dx.doi. org/10.1108/01443570910953595

PEKKARINEN, S.; ULKUNIEMI, P. Modularity in developing business services by platform approach. The International Journal of Logistics Management, v. 19, n. 1, p. 84-103, 2008. http://dx.doi. org/10.1108/09574090810872613

PERO, M. et al. A framework for the aligment of new product development and supply chains. Supply Chain Management: an International Journal, v. 15, n. 2, p. 115-128, 2010. http:// dx.doi.org/10.1108/13598541011028723

PESSÔA, M. V. P. Proposta de um método para planejamento de desenvolvimento enxuto de produtos 
de engenharia. 2006. 266 f. Tese (Doutorado em Engenharia Aeronáutica e Mecânica)-Instituto Tecnológico de Aeronáutica, São José dos Campos, 2006.

PESSÔA, M. V. P.; LOUREIRO, G.; ALVES, J. An approach to lean development planning. Complex systems concurrent engineering, part 4, p. 229-237, 2007.

PRAJOGO, D. I.; HONG, S. W. The effect of TQM on performance in R\&D environments: A perspective from South Korean firms. Technovation, v. 28, p. 855-863, 2008. http://dx.doi.org/10.1016/j.technovation.2008.06.001

QUESADA-PINEDA, H.; GAZO, R. Best manufacturing practices and their linkage to top-performing companies in the US furniture industry. Benchmarking: an International Journal, v. 14, n. 2, p. 211-221, 2007.

RANKY, P. G. Eighteen "monozukuri-focused" assembly line design and visual factory management principles with DENSO industrial exemples. Assembly Automation, v. 27, n. 1, p. 12-16, 2007.

REINSERTSEN, D. Rethinking lean NPD - A distorted view of lean product development. Strategic Direction, v. 23, n. 10, p. 32-34, 2007. http://dx.doi. org/10.1108/02580540710824310

RYTTER, N. G.; BOER, H.; KOCH, C. Conceptualizing operations strategy processes. International Journal of Operations \& Production Management, v. 27, n. 10, p. 10931114, 2007. http://dx.doi.org/10.1108/01443570710820648

RO, Y. K.; LIKER, J. K.; FIXSON, S. K. Evolving Models of Supplier Involvement in Design - The Deterioration of the Japanese Model in US Auto. IEEE Transactions on Engineering Management, v. 55, n. 2, p. 359-377, 2008. http://dx.doi.org/10.1109/TEM.2008.919733

ROH, J. J.; HONG, P.; PARK, Y. Organizational culture and supply chain strategy - a framework for effective information flows. Journal of Enterprise Information Management, v. 21, n. 4, p. 361-376, 2008.

ROTHER, M.; SHOOK, J. Aprendendo a Enxergar - Mapeando o fluxo de valor para agregar valor e eliminar o desperdício. São Paulo: Lean Institute Brasil, 2003.

ROZENFELD, H. et al. Gestão de desenvolvimento de produtos: uma referência para a melhoria do processo. São Paulo: Saraiva, 2006.

RYTTER, N. G.; BOER, H.; KOCH, C. Conceptualizing operations strategy processes. International Journal of Operations \& Production Management, v. 27, n. 10, p. 1093-1114, 2007.

SAAD, S. M.; GINDY, N. N. Z. Future shape of the responsive manufacturing enterprise. Benchmarking: an International Journal, v. 14, n. 1, p. 140-152, 2007.
SALAH, S.; RAHIM, A.; CARRETERO, J. A. The integration of Six Sigma and lean management. International Journal of Lean Six Sigma, v. 1, n. 3, p. 249-274, 2010. http:// dx.doi.org/10.1108/20401461011075035

SALIBA, M. A.; ZARG, A. V.; BORG, J. C. A modular, reconfigurable end effector for the plastics industry. Assembly Automation, v. 30, n. 2, p. 147-154, 2010. http:// dx.doi.org/10.1108/01445151011029781

SALZMAN, R. A. Manufacturing System Design: Flexible Manufacturing Systems and Value Stream Mapping. 2002. 126 f. Dissertação (Mestrado em Engenharia Mecânica)-Massachusetts Institute of Technology, Massachusetts, 2002.

SARKIS, J.; TALLURI, S.; GUNASEKARAN, A. A strategic model for agile virtual enterprise partner selection. International Journal of Operations \& Production Management, v. 27, n. 11, p. 1213-1234, 2007. http:// dx.doi.org/10.1108/01443570710830601

SARSHAR, M.; PITT, M. Adding value to clients - learning from four case-studies. Facilities, v. 27, n. 9-10, 2009, p. 399-412. http://dx.doi.org/10.1108/02632770910969649

SAWHNEY, R. et al. A modified FMEA approach to enhance reliability of lean systems. International Journal of Quality \& Reliability Management, v. 27, n. 7, p. 832-855, 2010.

SCHÄFER, H.; SORENSEN, D. J. Creating options while designing prototypes: value management in the automobile industry. Journal of Manufacturing Technology Management, v. 21, n. 6, p. 721-742, 2010. http://dx.doi. org/10.1108/17410381011064012

SENGE, P. M. A quinta disciplina. Rio de Janeiro: Best Seller, 2004

SETH, D.; SETH, N.; GOEL, D. Application of value stream mapping (VSM) for minimization of wastes in the processing side of supply chain of cottonseed oil industry in Indian context. Journal of Manufacturing Technology Management, v. 19, n. 4, p. 529-550, 2008.

SETIJONO, D.; DAHLGAARD, J. J. Customer value as a key performance indicator (KPI) and a key improvement indicator (KII). Measuring Business Excellence, v. 11, n. 2, p. 44-61, 2007.

SHAMSUZZOHA, A.; KYLLÖNEN, S.; HELO, P. Collaborative customized product development framework. Industrial Management \& Data Systems, v. 109, n. 5, p. 718-735, 2009. http://dx.doi. org/10.1108/02635570910957678

SHARIF, A. M.; IRANI, Z.; LLOYD, D. Information technology and performance management for build-to-order supply chains. International Journal of Operations \& Production Management, v. 27, n. 11, p. 1235-1253, 2007. http://dx.doi.org/10.1108/01443570710830610 
SHARMA, M.; KODALI, R. Development of a framework for manufacturing excellence. Measuring Business Excellence, v. 12, n. 4, p. 50-66, 2008.

SINGH, B.; GARG, S. K.; SHARMA, S. K. Development of index for measuring leanness - study of an Indian auto component industry. Measuring Business Excellence, v. 14, n. 2, p. 46-53, 2010.

SINGH, B.; GARG, S. K.; SHARMA, S. K. Lean can be a survival strategy during recessionary times. International Journal of Productivity and Performance Management, v. 58, n. 8, p. 803-808, 2009.

SMADI, S. A. Kaizen strategy and the drive for competitiveness - challenges and opportunities. Competitiveness Review: an International Business Journal, v. 19, n. 3, p. 203-211, 2009.

SNEE, R. D. Lean Six Sigma - getting better all the time. International Journal of Lean Six Sigma, v. 1, n. 1, p. 9-29, 2010. http://dx.doi.org/10.1108/20401461011033130

SOBEK, D. K. A Toyota-Chrysler comparison. 1997. Dissertation (Degree of Doctor of Philosophy Industrial and Operations Engineering)-University Michigan, 1997.

SOBEK, D. K.; SMALEY, A. Entendendo o pensamento A3 - um componente crítico do PDCA da Toyota. Porto Alegre: Bookman, 2010.

SPENDOLINI, M. J. Benchmarking. Tradução de Kátia Aparecida Roque. São Paulo: Makron Books, 1993.

SRAI, J. S.; GREGORY, M. A supply network configuration perspective on internacional supply chain development. International Journal of Operations \& Production Management, v. 28, n. 5, p. 386-411, 2008. http://dx.doi. org/10.1108/01443570810867178

SUMMERS, G. J.; SCHERPEREEL, C. M. Decision making in product development - are you outside-in or inside-out. Management Decision, v. 46, n. 9, p. 1299-1312, 2008.

TAM, V. M. Y.; TAM, C. M.; NG, W. C. Y. On prefabrication implementation for different project types and procurement methods in Hong Kong. Journal of Engineering, Design and Technology, v. 5, n. 1, p.68-80, 2007.

TAYLOR, D. H. Strategic considerations in the development of lean agri-food supply chain - a case study of the UK pork sector. Supply Chain Management: an International Journal, v. 11, n. 3, p. 271-280, 2006.

THOMAS, A.; BARTON, R. Integrating local suppliers in a global supply network. Journal of Manufacturing Technology Management, v. 18, n. 5, p. 490-512, 2007.

TRKMAN, P. et al. Process approach to supply chain integration. Supply Chain Management: An International Journal, v. 12, n. 2, p. 116-128, 2007.
TUHOLSKI, S. J. et al. Lean Comparison Using Process Charts of Complex Seismic Retrofit Projects. Journal of Construction Engineering and Management, p. 230-239, 2009.

ULRICH, K. T.; TUNG, K. Fundamentals of product modularity. ASME, 1991. v. 39. Issues in Design Manufacture Integration.

VISSER, M. et al. Structural ambidexterity in NPD processes: A firm-level assessment of the impact of differentiated structures on innovation performance. Technovation, v. 30, p. 291-299, 2010.

WAAL, A. A.; COUNET, H. Lessons learned from performance management systems implementations. International Journal of Productivity and Performance Management, v. 58, n. 4, p. 367-390, 2009.

WALTON, M. Strategies for Lean Product Development. Massachusetts Institute of Technology, 1999. Relatório de Pesquisa do LAI - Lean Aerospace Initiative.

WANG, J.; KLEINER, B. H. The evolution of R\&D Management. Management Research News, v. 28, n. 11-12, p. 88-95, 2005.

WANG, J.; LIN, W.; HUANG, Y. A Performance-oriented risk management framework for innovative $R \& D$ projects. Technovation, v. 30, p. 601-611, 2010.

WARD, A. Lean Product and Process Development. Estados Unidos: Lean Institute, 2007.

WEE, H. M.; WU, S. Lean supply chain and its effect on product cost and quality: a case study on Ford Motor Company. Supply Chain Management: an International Journal, v. 14, n. 5, p. 335-341, 2009.

WELlingS, T.; WILliAnS, M.; TENNANT, C. Understanding customers' holistic perception of switches in automotive. Applied Ergonomics, v. 41, p. 8-17, 2010.

WILLIAMS, S. A supplier development programme - the SME experience. Journal of Small Business and Enterprise Development, v. 14, n. 1, p. 93-104, 2007. http://dx.doi. org/10.1108/14626000710727917

WOUTERS, M. A Development Approach to performance measures - Results from a longitudinal case study. European Management Journal, v. 27, p. 64-78, 2009. http://dx.doi.org/10.1016/j.emj.2008.06.006

WU, L.; PARK, D. Dynamic outsourcing through process modularization. Business Process Management Journal, v. 15, n. 2, p. 225-244, 2009.

YANG, T. T.; LI, C. Competence Exploration and Exploitation in NPD - the modarating effects of enviromental dynamism and competitiveness. Management Decision, v. 49, n. 9, p. 1444-1470, 2011. 